\title{
Advances in the Knowledge of Quinoa Pests
}

\author{
Claus Rasmussen, ${ }^{1, *}$ Aziz Lagnaoui, ${ }^{2}$ and Peter Esbjerg ${ }^{3}$ \\ ${ }^{1}$ Departmento de Entomología, Museo de Historia Natural, Lima, Peru \\ ${ }^{2}$ International Potato Center, Lima, Peru \\ ${ }^{3}$ The Royal Veterinary and Agricultural University, Copenhagen, Denmark
}

\begin{abstract}
A wide range of quinoa pests are known throughout the world. The most serious of the Andean pests are Eurysacca melanocampta (Meyrick) and E. quinoae Povolný (Lepidoptera: Gelechiidae), found mainly in Peru and Bolivia, which cause considerable yield losses. Insects found elsewhere in the world are polyphagous pests constituting a wide range of potential pests if quinoa is implemented as a crop in those regions. Other major pests include a group of cutworms (Noctuidae). Apart from insects birds cause a major loss through foraging, damaging cotyledonous plants and inflorescences, with yield losses of up to $60 \%$.

Cultural practices and host plant resistances will be important components of integrated pest management (IPM). Biological control of the main pests is good; for example, up to $45 \%$ of Eurysacca melanocampta in the field are usually controlled by a range of parasitoid species as well as predators in the field.

Future research should focus on the main pests in order to reveal basic information on interactions with the host plant. Population carryover from one growth season to another and the role of environmental factors on insect development and population size should also be studied.
\end{abstract}

*Correspondence: Claus Rasmussen, Departmento de Entomología, Museo de Historia Natural, Av. Arenales 1256, Lima 14, Peru; E-mail: alrunen@yahoo.com.

61

DOI: $10.1081 / F R I-120018868$

Copyright (C) 2003 by Marcel Dekker, Inc.
8755-9129 (Print); 1525-6103 (Online) www.dekker.com 


\section{INTRODUCTION}

Quinoa Chenopodium quinoa Willdenow (Chenopodiaceae), is an important staple food crop of the Andean region of Latin America, mainly grown in dry and saline soils between 2500 and 4000 m.a.s.l. Quinoa has exceptional nutritive value with high protein quality and high content of several vitamins and minerals making it one of the most promising crops for the alleviation of malnutrition in Latin America and elsewhere (National Research Council, 1989).

Loss of yield due to pest attacks occurs mainly during the cropping season. Problems in the field include miners and borers eating leaves, stems, roots, and grains, chewing and sucking insects on foliage, and stem cutters, birds, and rodents feeding on mature grains (Gullan and Cranston, 1994; Mujica et al., 1998; Zanabria and Banegas, 1997). Pest attacks in storage may be significant (Jacobsen and Mujica, 2000).

\section{MAJOR PESTS OF QUINUA IN PERU AND BOLIVIA}

Among the most serious of the Andean pests are Eurysacca melanocampta (Meyrick) and E. quinoae Povolný (Gelechiidae), found throughout Peru and Bolivia. These pests are abundant and destructive at all stages of plant growth particularly during the maturation of grains. More detailed monitoring of both pests throughout the year would give us a better idea of the overlap of these two species in quinoa (Rasmussen et al., 2000a). Other major pests include a group of cutworms (Noctuidae), whose later larval instars cut emerging plants off near the ground (Aronia, 2000; Blanco, 1982; Rasmussen et al., 2000b; Zanabria and Banegas, 1997). Weevils Adioristus sp. (Curculionidae) in valleys of central Peru, and Diabrotica sp. (Chrysomelidae) in valleys of southern Peru, are also reported to cause damage to plants (Altamirano, 2000; Hidalgo and Jacobsen, 2000; Mercado and Lindo, 1998; Uceda, 1998).

The wide range of insects recorded from quinoa fields in Peru and Bolivia (Table 1) includes Coleoptera (Chrysomelidae Curculionidae Meloidae Melyridae Tenebrionidae) Diptera (Agromyzidae) Homoptera (Aphididae Cicadellidae) Lepidoptera (Gelechiidae Geometridae Noctuidae Pyralidae) and Thysanoptera (Thripidae) (Mujica, 1993; Mujica et al., 1998; Zanabria and Banegas, 1997; Zanabria and Mujica, 1977).

Apart from insects birds cause a major loss through foraging and damaging mature inflorescences, with yield loss of up to $60 \%$ (Orellano and Tillmann, 1984; Zanabria and Banegas, 1997; citation in Rasmussen et al., 2000b). Late in the season, a wide range of species can be observed feeding on the soft grains, including siskins (Carduelis spp.), eared dove (Zenaida auriculata), rufous-collared sparrow (Zonotrichia capensis), and white-throated sierra-finch (Phrygilus erythronotus) (Rasmussen, unpublished; Fjeldså and Krabbe, 1990). Rodents also feed on quinoa grains but are not commonly encountered in quinoa fields. They seem to be a more serious postharvest pest, when grains are being dried and in storage (Zanabria and Banegas, 1997).

\section{Fluctuation of Pest Populations}

In Peru and Bolivia, insects are present in the field during the entire season from late September-October to April-June. Weather conditions and a wide range of parasitoids 
Table 1. A tentative checklist of all pest and potential pest insects found in quinoa folds in Peru and Bolivia. Compiled from a variety of sources, species with questionmark "?" may be misidentifications.

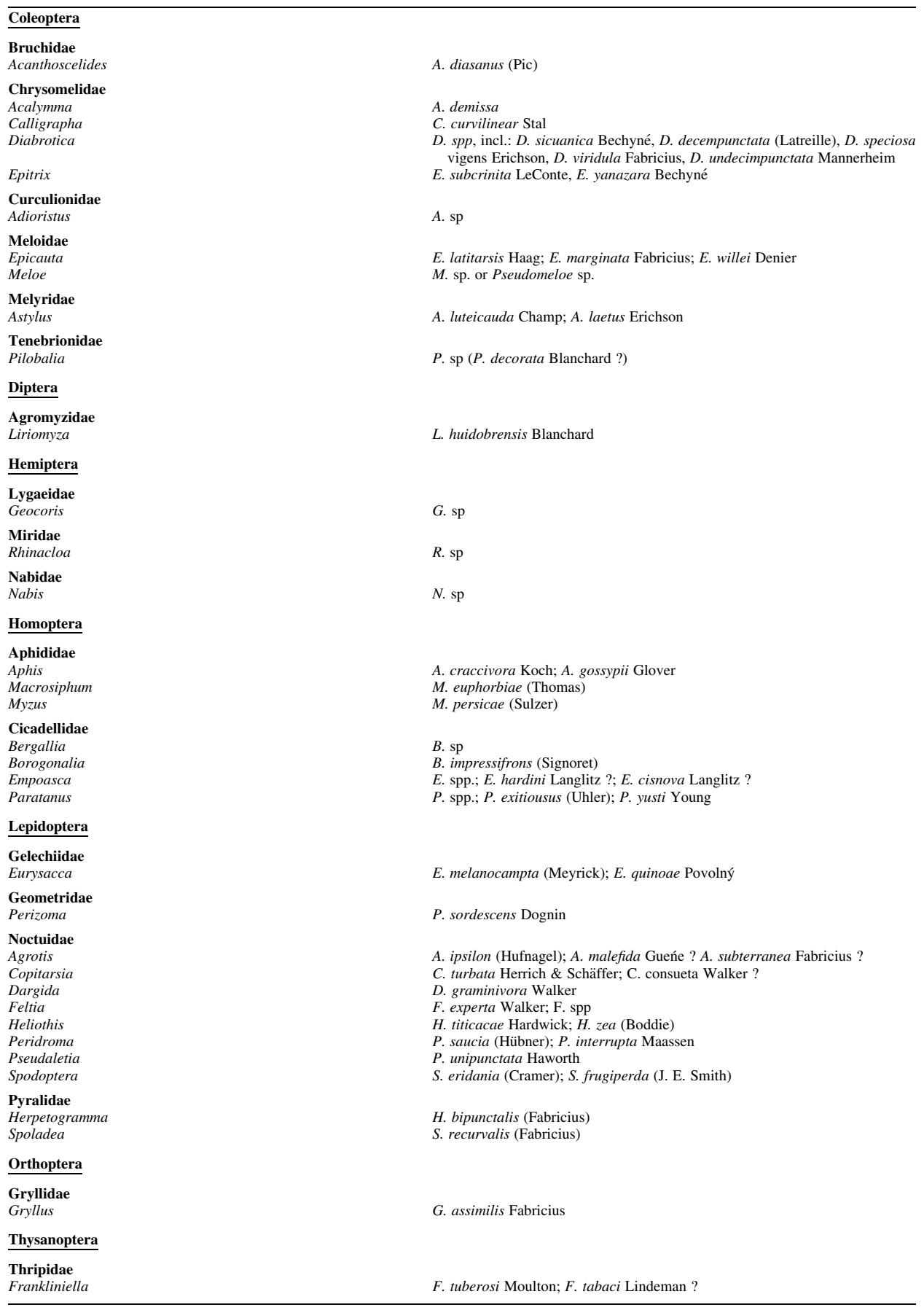


and predators control both pests and potential pests, and only few of these species reach population levels at which their damage is significant to humans.

Species of Eurysacca are usually not present until the first quinoa inflorescences appear, and remain present in the field with increasing population numbers until harvesting. Cutworms are present in highest numbers early during ramification (Saravia and Germán, 1988; Hidalgo and Jacobsen, 2000; Mujica, 1993).

Annual fluctuations in E. melanocampta populations from the Andean region have been demonstrated in Salinas de Garcí Mendoza in Bolivia, where their presence was evaluated biweekly throughout the 1982-1983, 1985-1986, and 1986-1987 seasons. The highest average number of larvae per plant per survey were recorded as 24, 18, and 46, respectively, for each survey season (Saravia and Calle, 1984; Saravia and Germán, 1988).

\section{Main Insect Pests}

The two species of Eurysacca can be recognized by their wing pattens. Eurysacca melanocampta has a longitudinal dark band on the wings and two dark spots surrounded by light scales. Eurysacca quinoae has two dark spots on the wing as well as some small dark spots at the apex of the wing, but it does not have a dark longitudinal band (Povolný, 1997).

Both species are ca. $8 \mathrm{~mm}$ long with a wing expansion of ca. $16 \mathrm{~mm}$ (Ochoa, 1990). The eggs are small, ca. $0.6 \mathrm{~mm}$ long and $0.3 \mathrm{~mm}$ wide. Five (I-V) instars exist pale green to yellow with several narrow red-maroon longitudinal bands. Pupae are dark maroon (Povolný and Valencia 1986; Ochoa, 1990; Zanabria and Banegas, 1997).

Eurysacca melanocampta is distributed throughout xeromontane habitats (approximately between 1900-4350 m a.s.1.) from Argentina and Chile in the south to Colombia in the north (Povolný and Valencia, 1986; Povolný, 1997). The other species, Eurysacca quinoae was recently described as a distributional-limited pest, but recent sampling efforts have shown that it is actually widespread in Peru, in some areas forming the main pest (Povolný, 1997; Rasmussen et al., 2000a).

Reproductive potential for E. melanocampta adult moths are ca. 300 eggs (Flavio, 1997). Phenological data state that development time for this species, egg to adult, ranges from 47 to 88 days in the field, mainly depending on temperature (Quispe, 1979; Flavio, 1997; Ochoa, 1990; Thomas, 1997; Ortiz, 2000).

Flavio (1997) raised E. melanocampta under controlled conditions in the laboratory. Larvae were held at $24 \pm 2^{\circ} \mathrm{C}$ and $55-65 \% \mathrm{RH}$ and fed were fresh quinoa leaves. Estimated degree-days for mean development time were $536 \mathrm{DD}$, using $5^{\circ} \mathrm{C}$ as the threshold (Buckingham and Bennett, 1996; Thomas, 1997). The actual threshold may be even lower for this Andean species, reducing the necessary amount of degree-days for development. The average temperature in Department of Junín, Huancayo district, Peru, from October to April, is $12.6^{\circ} \mathrm{C}$ with an average diurnal variation ranging from $6.1-19.2^{\circ} \mathrm{C}$ (1997: CIP records), whereas the average for the Department of Puno, Puno district, Peru, is $9.7^{\circ} \mathrm{C}$ ranging from $4.7-14.8^{\circ} \mathrm{C}$ (1964-1988: SENAMHI records). These are the two main quinoa producing departments of Peru.

First instar larvae are leaf miners of quinoa whereas later instars feed by chewing or scraping on foliage, with a preference for the inflorescence. Later instars make shelters by 
rolling leaves. Adults are active at dusk and night (Rasmussen unpublished; Zanabria and Banegas, 1997).

Host plants identified for E. melanocampta include the Chenopodiaceae quinoa (Chenopodium quinoa) and kaniwa (Ch. pallidicaule Aellen) as well as native species like Ch. ambrosioides L. a.o. (Zanabria and Banegas, 1997).

During and after the growing season of quinoa, Eurysacca spp. may enter diapause in the soil or switch to a wider range of host plants including wild Senecio spp. (Asteraceae) and cultivated tarwi, Lupinus mutabilis Sweet (Fabaceae), beans, Vicia faba L. (Fabaceae), and probably potato, Solanum tuberosum L. (Solanceae) (Chacón, 1963; Povolný, 1980; Povolný and Valencia, 1986; Zanabria and Banegas, 1997).

Further ecological studies on diapause population carryover from one quinoa season to another, and the role of environmental factors on insect development and population increase have not been conducted.

\section{Yield Loss and Pest Population Size}

Actual loss caused by insects depends on many factors and varies over and within season and location. The loss due to attack of Eurysacca spp. is considered severe and is estimated to range from an average yield loss of $15-18 \%$ and up to $50 \%$ in dry years in Peru (Blanco, 1982; Mujica, 1993; Zanabria and Banegas, 1997).

Studies with manipulated infestations have given some insight to insect density-todamage relationships for E. melanocampta (Blanco, 1994; Villanueva, 1978). One study included 14 levels of infestation (from three to 70 larvae per plant) of quinoa in the field, as well as a control without larvae infestation (Villanueva, 1978). The average yield loss of the Bolivian cultivar sajama in Puno was $58.8 \%$ at an infestation of 30 larvae and $85.0 \%$ at an infestation of 70 larvae, compared to the control. Infestation was made with II-III instar larvae exposed to quinoa for 36 days.

The relation between loss and infestation level is best described as an exponential growth function (Fig. 1) describing percentage loss, $F(x)$, due to the presence of $x$ larvae: $F(x)=2.1445 * \exp (0.0420 * x)(F=772.86, \quad P<0.001)$. The model does not take into account plant stress, duration of infestation physiological age of plants, or the importance of source-sink areas for pest populations, as well as the influence of temperature and rainfall (Cockburn, 1991; Teng, 1987). From the function, a simple table of insect densityto-damage relationships can be developed (Table 2).

Even though the relation between insert density and damage is exponential, and not additive, a simple conversion to amount of larvae per hectare can be made. In the study cited, the density of quinoa plants was 405,000 plants/ha. The yield loss ascribed to this pest in the literature ranges from 15\% (4.03 larvae per plant) to 50\% (17.51 larvae per plant).

The conclusions from the studies were that the economic threshold level was three to 15 larvae per plant (Blanco, 1994; Villanueva, 1978). In heavily infested quinoa fields of Puno and Bolivia, single plants have been recorded to host up to 150-200 larvae, with an average of 46 larvae during the peak season in favorable years (Saravia and Germán, 1988; Mujica, 1993; Zanabria and Banegas, 1997). 


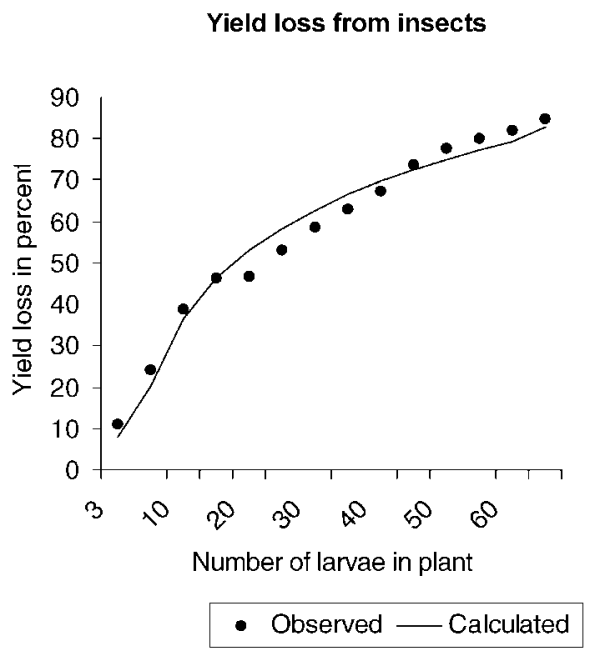

Figure 1. Observed and exponential relationship between the larvae infestation level and loss of production (g/plant).

\section{Other Minor Pest Groups}

Most of the other insects associated with quinoa in Peru and Bolivia are cosmopolitan polyphagous pests known to several crops and wild plants of the Andean region and elsewhere (Aréstegui, 1976). Occasionally, they constitute population sizes that are damaging also to the quinoa.

The Noctuidae group of cutworms is mainly represented in the field by the Copitarsia turbata Herrich \& Schäffer (Larrain, 1996). Cutworms cause damage at the beginning of the season, when emerging quinoa is cut off at the surface of the ground, or they attack the stem in later quinoa stages. Larvae are nocturnal and hide under stones or in the soil during the day (Borror et al., 1981; Vela and Quispe, 1988; Zanabria and Banegas, 1997). Pupae are probably over-wintering in the soil (Arce and Neder, 1992). The Population size of cutworms usually does not exceed one larvae per plant during the quinoa season, but during severe cutworm attacks, yield loss of up to $70 \%$ has been reported from Bolivia (Saravia and Calle, 1984; Saravia and Germán, 1988) The larvae has six (I-VI) instars, and the ovipositional potential for the adult female is more than 1000 eggs (Arce and Neder, 1992; Arce and Neder, 1993; Larrain, 1996). Developmental time in Huancayo is recorded as 37 days, estimated degree-days in Chile for mean development time were

Table 2. Percentage loss of quinoa yield per plant, related to the abundance of larvae in the field, expressed as number of larvae.

\begin{tabular}{lllllllllll}
\hline Loss & $10 \%$ & $20 \%$ & $30 \%$ & $40 \%$ & $50 \%$ & $60 \%$ & $70 \%$ & $80 \%$ & $90 \%$ & $100 \%$ \\
Number of larvae & 3.26 & 4.97 & 7.56 & 11.51 & 17.51 & 26.65 & 40.57 & 61.74 & 93.96 & 143.01 \\
\hline
\end{tabular}


$1238 \mathrm{DD}$, using $5^{\circ} \mathrm{C}$ as threshold and $825 \mathrm{DD}$ at a $10^{\circ} \mathrm{C}$ threshold (Buckingham and Bennett, 1996; Larrain, 1996; Thomas, 1997).

From Cusco, yield losses of $3-18 \%$ averaging $10 \%$ were recorded during the 1980-1981 season due to Geometridae caterpillars. Pyralidae caterpillars are also reported to cause yield loss (Blanco, 1982; Mujica et al., 1998).

Larvae of leaf-mining flies (Agromyzidae), recognized by their serpentine mines, can, under favorable conditions, cause severe damage to the leaves or the entire plant (Mujica et al., 1998).

Adults and larvae of phytophagous and pollen-eating beetles like Chrysomelidae, Curculionidae, and to lesser extent, Meloidea, Melyridae, and Tenebrionidae, attack almost every part of the plant and are serious pests when population sizes reach high levels (Borror et al., 1981; Mujica et al., 1998). From experimental quinoa fields in the valleys of southern Peru, the presence of 10 to 15 adults of Diabrotica sp. (Chrysomelidae) per plant caused yield losses of more than 20\% in the 1998-1999 season (Altamirano, 2000).

Sucking and biting insects of Aphididae and Cicadellidae are present in quinoa fields as potential pests, apart from their direct impact on the plant. These insects are known vectors of diseases, and their attacks can promote infestation of fungi (Borror et al., 1981; Mujica et al., 1998; Zanabria and Banegas, 1997).

\section{PEST ORGANISMS IN OTHER PARTS OF THE WORLD}

In other parts of the world where quinoa previously has not been cultivated, or only cultivated at a small scale, a different range of potential pests are described when quinoa is introduced.

\section{South America}

In Colombia and Ecuador, minor damages, are ascribed to Lepidopteran pests. Insects identified in the field include Coleoptera (Cucujidae), Diptera (Agromyzidae), and Lepidoptera (Gelechiidae, Geometridae, Noctuidae, and Pyralidae). All but Cucujidae are also found in Peru and Bolivia (Alissie and Onore, 1988; Reyes and Corredor, 1999). In areas where extensive fields ( $<1 \mathrm{ha}$ ) of quinoa are found, major damage has been ascribed to Copitarsia turbata as well as other cutworms (C. Nieto pers. comm.).

From Argentina and Chile, Eurysacca melanocampta and E. media Povolný is found scattered in quinoa fields, as well as Coleophoridae (Lepidoptera), Noctuidae, and Pyralidae, with only the Copitarsia turbata and Achryra similaris (Guenée) (Pyralidae) occasionally constituting major pests of quinoa (Mujica et al., 1999; Lamborot et al., 1999).

Many potential pests were sampled from experimental plantations of quinoa in Cuba. However, no species were abundant enough to cause serious damage (Barrientos, 1994; Vázquez and López, 1998).

\section{Elsewhere}

From northern Europe in Denmark and Poland Cnephasia sp. (Tortricidae Lepidoptera) as well as Aphis fabae L. (Aphididae Homoptera) and Lygus rugulipennis Poppius 
(Miridae Hemiptera) are reported from experimental quinoa fields (Gêsiñski, 2000; Jacobsen, 1993) whereas fields in Italy and Greece, and southern Europe are attacked by Epitrix subcrinita Le Conte (Chrysomelidae, Coleoptera), and emerging plants are attacked by leafhoppers (Cicadellidae, Homoptera) (P. Casini and C. Iliadis, pers. comm.).

In Africa, plant bugs (Hemiptera) and termites (Isoptera) are reported to cause damage in plantations of quinoa (Zuurbier, 1999).

\section{THE COMPONENTS OF PEST MANAGEMENT}

\section{Cultural Practices}

Few husbandry practices have been transferred to quinoa farmers. If such practices can be identified and their effect verified, they will provide integral components of integrated pest management (IPM), with none, or few, of the problems found in conjunction with the use of pesticides, as well as no additional cost to the Andean farmers.

Cultural practices making the environment less favorable for pest invasion include recommendation of sowing date, nutrient management and irrigation, planting density, and thinning crop rotation, mixed cropping, phytosanitation, and tillage practices (Dent, 1995; Sharma and Nwanze, 2000).

In quinoa production, crop rotation is recommended to break the continuity of the food chain for oligophagous pests (Mujica, 1993; Sharma and Nwanze, 2000; Zanabria and Banegas, 1997). Quinoa is rotated in 3- to five-year cycles with potato cereals, and legumes, such as tarwi (Lupinus mutabilis), oat, barley, or beans (Vicia faba) (Mujica, 1993; Zanabria and Banegas, 1997). Potato is always followed by quinoa, with residues from the previous year's fertilizer sufficient for the quinoa. Thus little to no additional fertilizer is required (Orellano and Tillmann, 1984; Aroni 2000). For small-scale farming, intercropping in the field with beans, tarwi and corn is recommended in Peru and Bolivia (Tapia, 1997; Zanabria and Banegas, 1997). In Ecuador, peas, Pisum sativum L. (Fabaceae), and flax Linum usitatissimum L. (Linaceae) is further used for intercropping (Alissie and Onore, 1988). Other recommendations to reduce pest attacks are to avoid quinoa in dry years and in poor soils, and to clear the field and surroundings effectively, in particular, for alternative host plants (Tapia, 1997; Zanabria and Banegas, 1997).

No estimate of the pest reduction from the above actions has been made, but these actions are believed to reduce pest levels, even though several of the crops are considered alternative host plants for the key pests Eurysacca spp. and other pests are polyphagous, probably attacking the entire rotation (Povolný, 1980; Povolný and Valencia, 1986; Zanabria and Banegas, 1997).

\section{Biological Control}

In Puno, the main parasitoids of E. melanocampta during 1986-1988 were Copidosoma gelechiae Howard (Encyrtidae) and Diadegma sp. (Ichneumonidae), constituting more than half the parasitoid community in some samples (Delgado, 1989). 
Recent (2000) surveys of E. quinoae from Puno found $77 \%$ of the parasitoids to be an unrecognized genus of Ichneumonidae, with much less significance from C. gelechiae and Diadegma sp. (2-20\% presence) (Rasmussen et al., 2000b). The parasitoid community of E. quinoae in central Peru is mainly constituted by Phytomyptera sp. (Tachinidae), with up to $95 \%$ of the parasitism by this species (Rasmussen unpublished).

The total parasitism of Eurysacca spp. in quinoa fields ranges from 15-45\% throughout Peru (Delgado, 1989; Ormachea and Quispe, 1993; Rasmussen et al., 2000b; Zanabria and Bargas, 1997). Povolný and Valencia (1986) found up to 60\% parasitism in E. melanocampta collected from potato in Colombia.

Predators important for the control of both species of Eurysacca include Coleoptera (Carabidae Cicindelidae, and Coccinellidae), Diptera (Tachinidae), Hymenoptera (Encyrtidae, Braconidae, Ichneumonidae), and Neuroptera (Chrysopidae) (Delgado, 1989; Mujica, 1993; Zanabria and Mujica, 1977).

Studies on control of the cutworm Copitarsia turbata in vegetables and crops from Argentina and Chile as well as in Peru have demonstrated up to 57\% parasitism solely from Meteorus chilensis Porter (Braconidae) as well as other parasitoids of Braconidae, Ichneumonidae, Sphecidae (Hymenoptera), Trichogrammatidae, Tachinidae, and predators of Hemiptera (Anthooridae, Lygaeidae, Miridae, Nabidae) and Neuroptera (Chrysopidae) (Alcala, 1978; Rojas, 1982; Lamborot et al., 1995; Neder and Arce, 1991).

The potential for utilization of natural enemies in the biological control of Eurysacca spp. and Copitarsia turbata are thus good, as high levels of parasitism have been found. Studies on the activity periods, efficiency, and usefulness of the main parasitoids should be conducted as well as studies on how to encourage the activity of natural enemies.

\section{Biopesticides}

Potential control of pests with biopesticides involves the use of pheromones, bacteria, viruses, and antifeedants. Experiments have been carried out with infestation of the granulosis virus reaching levels of 50\% control of Eurysacca melanocampta (Calderón et al., 1996; Zanabria and Banegas, 1997). Other types of viruses may be isolated from the larvae and used in control, as preliminary screening has shown the presence of the Nucleo Polyhedrosis Virus (Rasmussen unpublished). Studies on antifeedants include observations on Minthostachys spp. (Laminaceae) with some control effect of pests (Gallegas et al., 1982; Saravia, 1998). Pheromones have so far not been isolated for E. melanocampta or E. quinoae.

\section{Host Plant Resistance}

Preliminary observations indicate that sweet cultivars are more susceptible to pest attacks than bitter ones and that cultivars with lax inflorescences, e.g., Quillahuamán-INIA show partial resistance to E. melanocampta (Gamarra et al., 1997). Screening of 555 quinoa accessions for resistance to degree of larvae attack by E. melanocampta demonstrated positive relationships between larvae infestation and compact, dark-colored, inflorescences. However, no, or only poor, significant relations could be demonstrated to 
larvae density and form of inflorescence, light to red colors, or saponin content (Castillo, 1978; Zanabria et al., 1977).

Another study demonstrated, through systematic samplings throughout the season, that the insect species has different preferences for quinoa cultivars. However no relation to plant characteristics was found (Ruíz, 1995).

\section{Chemical and Other Control}

Pest attacks are currently not controlled in Peru and Bolivia, or if so, only controlled with insecticides. Andean farmers mainly use pesticides of the synthetic pirethroids type and even the use of a kerosene solution has been described as well as the burning of rubber in the field to repel adult moths (Valdivia et al., 1997; Zanabria and Banegas, 1997). In central Peru, traditional farming practice includes application of ashes to the soil after sowing to prevent abundance of lepidopteran larvae (Orellano and Tillmann, 1984).

Problems with the use of insecticides include development of insecticide resistance, secondary pests, elimination of natural enemies, resurgences, loss of biodiversity, environmental contamination, and human health hazards (Hough-Goldstein and Hahn, 1992; Jilani and Saxena, 1990; Shanower et al., 1997). For the local farmer, the main concern of yield-increasing insecticides, however, is the high cost of these products (Jackai, 1993).

Integrated pest management may include the use of chemical control of pest populations, but the use should be based on economic threshold levels and should not be generally applied (Pimentel, 1997).

\section{DISCUSSION}

Integrated pest management (IPM) for the control of pest attacks in quinoa is still not well implemented. Chemical control is the only control in many parts of Peru because of lack of data on proper cultural and biological control of pests. Current recommendations to avoid high pest populations include the use of crop rotation and general application of chemical pesticides.

In order to obtain functional IPM components for controlling pests, there has to be a quantitative base to estimate the problem (Teng, 1987). Short-term research should establish the importance of various quinoa cultivars and other host plants, for the survival of the main pests, while long-term studies should establish the economic injury level or action threshold, reveal population dynamics of the pests, and indicate spatial and temporal variation in pest attacks. The role of environmental factors on insect development and population increase, and the use of natural enemies for control.

A crop that compares to quinoa in several aspects is sorghum Sorghum bicolor (L.) Moench (Poaceae). Sorghum is the world's fifth most important cereal and cultivated in many parts of the world, and now a part of the research program for the Consultative Group for International Agricultural Research Institutes (CGIAR), it has been subject to studies for 50 years (Sharma and Nwanze, 2000). Current activities include establishing a comprehensive database using Geographical Information System (GIS) maps for spatial 
analysis of insect pests and natural enemy occurrence, distribution, and on-farm losses. Investigations have been conducted on the impact of soil and crop management on pest levels, and there has been screening of thousands of accessions for resistance to pests. Natural insecticides have been identified, and the use in the field has been promoted to farmers (ICRISAT, 1996; Sharma and Nwanze, 2000).

The time frame for sorghum research has been long, and, furthermore, complicated by many severe pests in different parts of the world. Quinoa is still facing only a few major pests within its natural range, though new pests and potential pests have been registered for most areas where quinoa has only recently been introduced.

An integrated pest management strategy for quinoa can be adopted, but basic research is urgently needed before we can proceed with scientifically approved management recommendations. Advances in quinoa pest research should try to adopt experiences from other crops, like sorghum, in order to develop recommendations that are accessible to the poor, small-scale Andean farmers.

Quinoa production is constrained by pest attacks. Host-plant resistance in conjunction with natural enemies and cultural practices should form the base of an integrated pest management in quinoa, which will strengthen the economy for local farmers in poor Andean regions. This strategy should be implemented in an organic production system of the crop, leading to increased exportation of quinoa to the United States, Japan, and Europe, followed by improved economy for quinoa producers and developing countries.

\section{ACKNOWLEDGMENTS}

The study was funded by DANIDA/RUF Denmark (CR). We are grateful to S.-E. Jacobsen (CIP) for advise and comments P. Delgado A. Mujica R. Ortiz A. Perez E. Zanabria and E. Yabar thought us on their experiences with quinoa pests in Peru and H.C. Sharma shared a manuscript on the IPM activities on sorghum with us.

Specimens will be deposited in the Entomological Museum of Universidad Nacional Agraria La Molina, Lima, Peru. Identifications were done by Ole Karsholt of the Zoological Museum, University of Copenhagen Denmark, (E. quinoae and E. melanocampta) James E. O'Hara, Systematic Entomology Section, Agriculture y Agri-Food Canada (Phytomyptera sp.) and Ilari E. Sääksjärvi, Zoological Museum, University of Turku Centre for Biodiversity, Finland (Ichneumonidae gen. n.). Harold Hidalgo and O. Zegarra supported in other ways.

\section{REFERENCES}

Alcala, P. (1978). Tachinidos parásitos de Copitarsia turbata Herr.-Schäff. en el Valle del Mantaro. Rev. Peruana Entomol. 21(1):126.

Alissie, E., Onore, G. (1988). Ciclo biologico de Copitarsia sp. 2, Noctuido asociado a Chenopodium quinoa (Chenopodiaceae) y lista de otros insectos perjudiciales. In: Memorias de VI Congreso Internacional sobre cultivos Andinos, Quito, Ecuador, 95-98. 
Altamirano, A. M. (2000). Informe de Experimento Concluido, Ensayo Regional de Quinua (Ayacucho), 99.30.14 Ayacucho (Peru): INIA.

Arce, M. G., Neder, L. E. (1992). Aspectos bioecologicos de Copitarsia turbata (HerrichSchäffer) (Lepidoptera: Noctuidae) importantes de la determinación del daño económico en cultivos de Lactuca sativa L. de la Quebrada de Huamahuaca, Jujuy, Argentina. Rev. Sociedad Entomol. Argentina 91:73-87.

Arce, M. G., Neder, L. E. (1993). Morfología de los estados inmaduros y aspectos etológicos de Copitarsia turbata (Herrich-Schäffer) (Lepidoptera: Noctuidae). Netropica 39(101-102):29-33.

Aréstegui, A. (1976). Plagas de la Papa en Andahuaylas-Apurímac. Rev. Peruana Entomol. 19:97-98.

Aroni, G. (2000). Manejo y producción actual de quinua en Bolivia. In: Jacobsen, S-E., Portillo, Z., eds. Primer Taller Internacional sobre Quinua - Recursos Genéticos y Sistemas de Producción, 10-14 May, 1999. Peru: UNALM, In press.

Barrientos, A. (1994). Una nota sobre la población de insectos en Chenopodium quinoa Wild. Rev. Cubana Ciencias Agríc. 28:359-361.

Blanco, M.C. (1982). Evaluación de danos de Scrobipalpula sp. y Perisoma sp. en el cultivo de quinua en la zona del Cusco. In: III Congreso Internacional de Cultivos Andinos, La Paz, Bolivia, 133-135

Blanco, A. (1994). Umbral económico de kcona kcona Eurysacca melanocampta (Lepidoptera, Gelechiidae) en quinua (Chenopodium quinoa Willd.). Ingeniero Agrónomo, Thesis for Ingeniero Agronomo, UNA, Puno, Peru.

Borror, D. J., de Long, D. M., Triplehorn, C. A. (1981). Introduction to the study of insects. 5th ed. Philadelphia: Saunders College.

Buckingham, G. R., Bennett, C. A. (1996). Laboratory biology of an immigrant Asian moth Parapoynx diminutalis (Lepidoptera: Pyralidae), on Hydrilla verticillata (Hydrocharitaceae). Florida Entomologist 79(3):353-363.

Calderón, R., Becerra, A., Marquez, A. (1996). Expectativas del virus granulosis Phthorimaea operculella para el control de otros lepidópteros. IV Reunión Nacional de la Papa: Compendio de Exposiciones. Cochabamba, Bolivia: IBTA, pp. $107-108$.

Castillo, J. Evaluación de 555 líneas de quinua (Chenopodium quinoa Willd.) al ataque del "Gusano pegador de hojas y destructor de panoja" (Scrobipalpula sp.) en el distrito de Puno Thesis UNA, Thesis for Ingeniero Agronomo, UNA, Puno, Peru.

Chacón, C. (1963). Gnorimoschema sp. (Gelechidae - Lepidoptera) en Quinoa. Rev. Peruana Entomol, 6:15-20.

Cockburn, A. (1991). An Introduction to Evolutionary Ecology. Oxford: Blackwell Science.

Delgado, P. E. (1989). Determinación Taxonómica y Porcentaje de Parasitismo de Insectos Benéficos Sobre Eurysacca melanocampta Meyrick "Kcona Kcona" en Quinua. Thesis for Biologo, UNA, Puno, Peru.

Dent, D. (1995). Integrated pest Management. London: Chapman \& Hall.

Fjeldså, J., Krabbe, N. (1990). Birds of the High Andes. Zoological Museum and Apollo.

Flavio, T. (1997) Biología de la Eurysacca Melanocampta Meyrick en Laboratorio Thesis UNCP, Huancayo, Thesis for Ingeniero Agronomo, UNCP, Huancayo, Peru. 
Gallegos, J., Díaz, J., Jayo, E. (1982). Evaluación de la planta repelente "muña" (Minthostachys sp.) en el control de Scrobipulpa sp. (Lep.: Gelechiidae) en quinoa. In: XXV Convención nacional de entomología, Huaraz, Peru 35-36.

Gamarra, M., Quillahuamán, A., Del Carpio, A. (1997). Variedad de Quinua Quillahuamán-INIA. Serie plegable 10-97, Lima (Perú).

Gêsiñski, K. (2000). American and European test of quinoa (Chenopodium quinoa Willd.) in Poland. Bydgoszcz, Poland.

Gullan, P. J., Cranston, P. S. (1994). The insects: An Outline of Entomology. London: Chapman \& Hall.

Hidalgo, W., Jacobsen, S-E. (2000). Principales plagas del cultivo de la quinua en la sierra central del Perú y las perspectivas de control integrado. In: Jacobsen, S-E., Portillo, Z., eds. Primer Taller Internacional Sobre Quinua-Recursos Genéticos y Sistemas de Producción, 10-14 May, 1999. Peru: UNALM, In press.

Hough-Goldstein, J., Hahn, S. P. (1992). Antifeedant and oviposition deterrent activity of an aqueous extract of Tanacetum vulgare L. on two cabbage pests. Environ Entomol. 21(4):837-844.

ICRISAT, (1996). ICRISAT Asia Region Annual Report 1995. Andhra Pradesh: ICRISAT. Jackai, L. E. N. (1993). The use of neem in controlling cowpea pests. ITIA Res. 7:5-10. Jacobsen, S-E. Quinoa: A Novel Crop for European Agriculture Ph.D. Thesis, Denmark KVL.

Jacobsen, S. E., Mujica, A. (2000). Almacenamiento de la semilla de quinua. In: Jacobsen, S-E., Portillo, Z., eds. Primer Taller Internacional sobre QuinuaRecursos Genéticos y Sistemas de Producción, 10-14 May, 1999. Peru: UNALM, In press.

Jilani, G., Saxena, R. C. (1990). Repellent and feeding deterrent effects of turmeric oil, sweetflag oil, neem oil, and a neem-based insecticide against lesser grain borer (Coleoptera: Bostrychidae). J. Econ. Entomol. 83(2):629-634.

Lamborot, L., Arretz, P., Guerrero, M. A., Araya, J. E. (1995). Parasitismo de huevos y larvas de Copitarsia turbata (Herrich y Schaffer) (Lepidoptera: Noctuidae) en cultivos hortícolas en la región metropolitana. Acta Entomol. Chilena 19:129-133.

Lamborot, L., Guerrero, M. A., Araya, J. E. (1999). Lepidópters asociados al cultivo de la quinoa (Chenopodium quinoa Willdenow) en la zona central de Chile. Boletin de sanidad vegetal plagas 25:203-207.

Larrain, P. (1996). Biología de Copitarsia turbata (Lep Noctuidae) bajo ambiente controlado. Agric. técnica (Santiago) 56:220-223.

Mercado, R., Lindo, E. (1998). Estudio preliminar del ciclo biológico de Adioristus sp. en zanahoria. In: XL Convención nacional de entomología, Lima, Peru, 4.

Mujica, A. (1993). Cultivo de Quinua. Lima: INIA.

Mujica, A., Jacobsen, S-E., Izquierdo, J., Marathee, J. P. (1998). Prueba Americana y Europea de Quinoa (Chenopodium Quinoa Willd.). Puno: FAO.

Mujica, A., Jacobsen, S-E., Bertero, D., Gonzalez, J. (2000). Un recorrido por el nor oeste Argentina buscando quinua. In: Jacobsen, S.-E., Portillo, Z., eds. Primer Taller Internacional sobre Quinua - Recursos Genéticos y Sistemas de Producción, 10-14 May, 1999. 1999. Peru: UNALM, In press. 
National Research Council, (1989). Lost Crops of the Incas: Little-Known Plants of the Andes with Promise for Worldwide Cultivation. National Academy.

Neder, L. E., Arce, M. G. (1991). Meteorus chilensis Porter (Hymenoptera: Braconidae) natural de Copitarsia turbata (Herrich-Schäffer) (Lepidoptera: Noctuidae) en zonas de la Quebrada de Huamahuaca. Jujuy. Neotropica. 37(98):137-144.

Ochoa, R. Ciclo Biologica de la Polilla de la Quinoa (Eurysacca kelanocampta Meyrick) Thesis, Cusco (Peru) UNSAAC, Thesis for Biologo, UNSAAC, Cusco, Peru.

Orellano, H., Tillmann, H. J. (1984). La quinua en Yanamarca, prov. de Jauja. Boletín de Lima. 35:55-64.

Ormachea, E., Quispe, D. (1993). Evaluacion de parasitoides de la "polilla de la quinua" Eurysacca melanocampta, en el Cusco. In: XXXV Convención nacional de entomología, Arequipa, Peru, 22.

Ortiz, R. (2000). Insectos plagas en quinoa. In: Jacobsen, S-E., Portillo, Z., eds. Primer Taller Internacional sobre Quinua-Recursos Genéticos y Sistemas de Producción, 10-14 May, 1999. Peru: UNALM, In press.

Pimentel, D. (1997). Techniques for Reducing Pesticide Use. Chichester: Wiley \& Sons.

Povolny, D. (1980). Die bisher bekannten futterpflanzen der tribus Gnorimoschemini (Lepidoptera Gelechiidae) und deren bedeutung für taxonomisch-ökologische erwägungen. Acta Univ. Agric. Facultas Agron. 28(1):189-210.

Povolny, D., Valencia, L. (1986). Una palomilla de papa nueva para Colombia. In: Memorias del curso sobre control integrado de plagas de papa, Bogota, Colomia, $33-35,113$.

Povolny, D. (1997). Eurysacca quinoae sp.n.-a new quinoa-feeding species of the tribe Gnorimoschemini (Lepidoptera, Gelechiidae) from Bolivia. Steenstrupia 22:41-43.

Quispe, H. (1979). Biología y comportamiento del minador pegador de hojas y destructor de panojas Scrobipalpula sp. (Lepidoptera, Gelechiidae) en quinua. Thesis for Ingeniero Agronomo, UNA, Puno.

Rasmussen, C., Jacobsen, S-E., Lagnaoui, A. (2001). Las polillas de quinua. (Chenopodium quinoa Willd.) en el Peru: Eurysacca (Lepidoptera: Gelechiidae), Rev. Peruana Entomol. 42: 57-59.

Rasmussen, C. Jacobsen, S-E., Lagnaoui, A., Esbjerg, P. (2000). Plagas de quinua (Chenopodium quinoa Willd.) en la zona andina. In: II Congreso Internacional de Agricultura en Zonas Aridas, Iquique, Chile 42.

Reyes, L. M., Corredor, G. (1999). Prueba Americana y Europea de Quinua en la Sabana de Bogota, Colombia. Colombia: UNC.

Ruíz, D. Entomofauna Asociada en Cuatro Variedades de Quinua en la Localidad de Sicaya Thesis, Huancayo (Peru) UNCP, Thesis for Ingeniero Agronomo, UNCP, Huancayo, Peru.

Saravia, R., (1998). Resumen de investigaciones sobre el control de las plagas de la quinoa en la estación experimental Patacamaya. In: Memorias avances de la investigación agrícola en Bolivia, La Paz, 63-67.

Saravia, R., Calle, E. (1984). Fluctuaciones poblacionales de insectos en el cultivo de la quinua. In: IV Congreso Internacional de cultivos andinos;: Narino, Colombia, $228-232$. 
Saravia, R., Germán, M. (1988). Fluctuaciones poblacionales de larvas de insectos asociados al cultivo de la quinua en salinas de Gacia Mendoza. In: VI Congreso Internacional sobre cultivos andinos; Quito, Ecuador, 76-79.

Shanower, T. G., Yoshida, M., Peter, A. J. (1997). Survival, growth, fecundity, and behavior of Helicoverpa armigera (Lepidoptera: Noctuidae) on pigeonpea and two wild Cajanus species. J. Economic Entomol. 90(3):837-841.

Sharma, H.C., Nwanze, K.F. (2000). Insect Pests of Sorghum and Their Management, submitted.

Tapia, M. E. (1997). Cultivos Andinos Subexploitation y su Aporte a la Alimentacion. 2nd ed. Santiago: FAO.

Teng, P. S. (1987). Crop Loss Assessment and Pest Management. St. Paul: APS.

Thomas, D. B. (1997). Degree-day accumulations and seasonal duration of the preimaginal stages of the Mexican fruit fly (Diptera: Tephritidae). Florida Entomol. 80:71-79.

Uceda, E. (1998). Observaciones sobre evaluación del incremento de la infección por el Adioristus sp. (Curculionidae) en cultivos varios del valle del Mantaro-Perú. In: XL Convención nacional de entomología, Lima, Peru, 33-34.

Valdivia, R., Paredes, S., Zegarra, A., Choquehuanca, V., Reinoso, J. (1997). Manual del Productor de Quinua. Lima: CIRNMA.

Vázquez, L., López, D. (1998). Incidencia de plagas de almacén en semillas de quinua (Chenopodium quinua Willd). Fitosandidad (Cuba) 2:69-70.

Vela, A., Quispe, A. (1988). Plagas de los cultivos de papa y maíz. Obispo Martínez.

Villanueva, S. Determinación del "Umbral económico" y "nivel critico" de "Kcona kcona" (Scrobipalpula sp.) en quinua (Chenopodium quinua Willd.) Thesis, Puno (Peru) UNA, Thesis for Ingeniero Agronomo, UNA, Puno, Peru.

Zanabria, E., Banegas, M. (1997). Entomología Economica Sostenible. Puno: UNAP.

Zanabria, E., Mujica, A. (1977). Evaluación de insectos plagas de la quinoa (Chenopodium quinoa Willd) en el departamento de Puno. In: XX Convención nacional de entomologÍa, Arequipa, Peru 36-37.

Zanabria, E.R., Rosas, M., Castillo, W. (1977). Evaluacion de la "K'ona k'ona," Scrobipalpula sp. (Lepidoptera-Gelechiidae) en. 555 líneas de quinua (Chenopodium quinoa Wild). In: XX convención nacinoal de entomología, Arequipa, Peru, 40.

Zuurbier, J. (1999). American and European Test of Quinoa. Namibian Quinoa Cultivar Screening Test 1999. Windhoek: Ministry of Agriculture. 